Check for updates

Cite this: RSC Adv., 2017, 7, 19439

Received 6th March 2017

Accepted 22nd March 2017

DOI: $10.1039 / \mathrm{c} 7 \mathrm{ra02702h}$

rsc.li/rsc-advances

\section{Addressing the mid-point of polymer chains for multiple functionalization purposes through sequential thiol-epoxy 'click' and esterification reactions $\dagger$}

\author{
Ikhlas Gadwal, ${ }^{a}$ Taejun Eom, (D) a JiHyeon Hwang, ${ }^{a}$ Youngson Choe, ${ }^{\text {b }}$ Joona Bang ${ }^{a}$ \\ and Anzar Khan (D)*a
}

A synthetic strategy is devised for the preparation of mid-chain multifunctional polymers. In this strategy, small molecules carrying one or two epoxide units along with two polymerization-initiating sites were prepared in two to three synthetic steps. Atom transfer radical polymerization (ATRP) of methylmethacrylate (MMA) monomer using the newly designed initiators gave rise to epoxide-mid-reactive polymers. A careful chain cleavage study confirmed the midpoint location of the reactive site(s) on the polymer chain. Dualmodification of these reactive epoxide unit(s) through sequential thiol-epoxy and esterification reactions then afforded the midpoint multiply functionalized polymeric structures. Due to compatibility of the ATRP process with the reactive epoxide unit(s) and the cascade nature of the functionalization processes, the present strategy is free from the protective-group requirement of organic synthesis. Moreover, it allows for varying the number and nature of functionalities at the midpoint of a polymer chain.

\section{Introduction}

Post-polymerization modification of polymers is a valuable tool in generating functional soft materials. ${ }^{1-8}$ In this regard, sidechain $^{1-5}$ and end-chain ${ }^{6-8}$ polymer functionalization has received enormous attention. General methods for addressing the polymer mid-chain for functionalization processes, however, are relatively few.-12 Strategies seeking further increase in the molecular complexity at the midpoint of a polymer chain by carrying out more than one protective-group-free functionalization step remains, to the best of our knowledge, unknown. Towards this end, we demonstrate a modular strategy for multiple functionalization of the polymer mid-chain through sequential application ${ }^{13}$ of thiol-epoxy 'click'14 and esterification reactions. The devised approach is free from protective-group requirements and allows for adjusting the number and nature of functional groups at the middle of a polymer chain (Scheme 1).

Our approach relies on the functional group tolerance of the ATRP process ${ }^{15-20}$ that allows for the preparation of polymers substituted with reactive epoxide groups ${ }^{21}$ at the centre of a polymer chain. These epoxide units can undergo a ring opening reaction with a thiol molecule to form a thio-ether

${ }^{a}$ Department of Chemical and Biological Engineering, Korea University, Seoul 02841, Korea.E-mail: anzar@korea.ac.kr; Tel: +82 232904859

${ }^{b}$ Department of Chemical Engineering, Pusan National University, Pusan, 46241, Korea

† Electronic supplementary information (ESI) available: Synthesis and characterization details are provided. See DOI: $10.1039 / \mathrm{c} 7 \mathrm{ra02702h}$

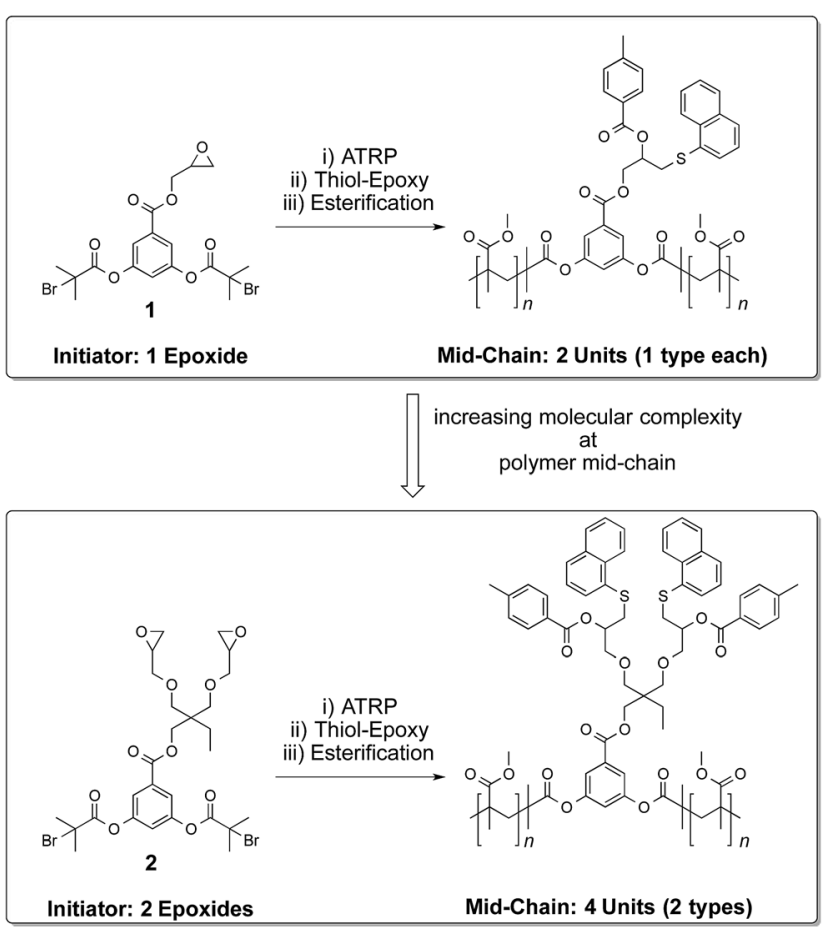

Scheme 1 Application of orthogonal and sequential processes to address polymer mid-chain for multiple functionalizations. 
linkage. ${ }^{\mathbf{1 4 2 0 , 2 2 - 2 4}}$ This base-catalyzed chemistry is established to be an efficient process that is capable of transforming thousands of epoxide repeat units into functionalized thio-ether linkages. The process is practically simple and proceeds under ambient conditions. An added advantage of this chemistry is that a reactive hydroxyl group is produced upon completion of the coupling reaction. This secondary hydroxyl group, although less reactive than the primary hydroxyl group, can be converted into an ester moiety upon reaction with an acid chloride molecule. ${ }^{25}$ This sequential functionalization processes gives rise to doubly functionalized structures in a protective-group-free fashion. Commercial availability of a variety of functional thiol and acid chloride molecules further enhances the scope of the present strategy in the preparation of functional materials.

\section{Experimental details}

\section{Synthesis of 1a}

To a stirring solution of bromoisobutyryl bromide (10.44 g, $45.41 \mathrm{mmol}$ ) in THF (40 mL) was added triethylamine (TEA) (8.66 g, $85.64 \mathrm{mmol}$ ) drop wise at $5{ }^{\circ} \mathrm{C}$ and stirring was continued for another $20 \mathrm{~min}$. To this reaction mixture was added 3,5-dihydroxybenzoic acid (2.0 g, $12.97 \mathrm{mmol})$ in THF (25 $\mathrm{mL})$ drop wise through a syringe pump $\left(0.86 \mathrm{~mL} \mathrm{~min}^{-1}\right)$ at $-5{ }^{\circ} \mathrm{C}$. The reaction mixture was stirred for 2 hours at $-5{ }^{\circ} \mathrm{C}$ and then warmed up to $0{ }^{\circ} \mathrm{C}$. After this, the triethylamine salts formed during the reaction were removed by filtration. The filtrate was concentrated under reduced pressure and the crude material obtained was dissolved in DCM $(50 \mathrm{~mL})$ and washed with water $(2 \times 50 \mathrm{~mL})$ and brine $(20 \mathrm{~mL})$. The organic layer was dried over $\mathrm{Na}_{2} \mathrm{SO}_{4}$ and concentrated under reduced pressure. The crude product was then purified by silica gel column chromatography using a DCM : MeOH solvent gradient (98: 2 to $96: 4)$. The resulting brown solid was further purified by crystallization from a DCM : hexane mixture to afford $2.12 \mathrm{~g}$ of the product as a white solid (yield $=36 \%) .{ }^{1} \mathrm{H}-\mathrm{NMR}(\delta, \mathrm{ppm}, 300$ MHz, DMSO- $d_{6}$ ): 13.59 (br s, $\left.1 \mathrm{H}\right), 7.67$ (d, $\left.J=2.24 \mathrm{~Hz}, 2 \mathrm{H}\right), 7.41$ $(\mathrm{t}, J=2.24 \mathrm{~Hz}, 1 \mathrm{H}), 2.05(\mathrm{~s}, 12 \mathrm{H}) ;{ }^{13} \mathrm{C}-\mathrm{NMR}(\delta, \mathrm{ppm}, 75 \mathrm{MHz}$, DMSO- $d_{6}$ ): $169.29,165.45,150.81,133.39,120.10,119.50,56.83$, 29.89; ESI-MS $m / z=472.92[\mathrm{M}+\mathrm{Na}]^{+}$(calcd 472.93 for $\mathrm{C}_{15^{-}}$ $\left.\mathrm{H}_{16} \mathrm{Br}_{2} \mathrm{O}_{6} \mathrm{Na}\right)$; IR $\left(\mathrm{cm}^{-1}\right): 2939,1754,1696,1586,1462,1443$, 1406, 1387, 1370, 1299, 1255, 1133, 1095, 1007, 986, 925, 770, 732, 654, 602, 572 .

\section{Synthesis of 1}

To a stirring solution of $1 \mathrm{a}(1.9 \mathrm{~g}, 4.2 \mathrm{mmol})$, glycidol $(0.59 \mathrm{~g}$, $7.98 \mathrm{mmol})$, and 4 -( $N, N^{\prime}$-dimethylamino)pyridinium-4toluenesulfonate (DPTS) $(0.23 \mathrm{~g}, 0.84 \mathrm{mmol})$ in DCM $(30 \mathrm{~mL})$, was added dicyclohexylcarbodiimide (DCC) $(1.04 \mathrm{~g}, 5.04 \mathrm{mmol})$ in several portions at $0{ }^{\circ} \mathrm{C}$. The resulting reaction mixture was then stirred at room temperature for 12 hours. After this time, the reaction mixture was cooled to $0{ }^{\circ} \mathrm{C}$. This resulted in precipitation of dicyclohexylurea (DCU) that was removed through filtration. The filtrate was concentrated under reduced pressure and the crude thus obtained was purified by silica gel column chromatography using heptane : EtOAc solvent gradient (95: 5 to $85: 15$ ) to afford $0.94 \mathrm{~g}$ of the product as a white solid (yield $=44 \%$ ). ${ }^{1} \mathrm{H}-\mathrm{NMR}\left(\delta\right.$, ppm, $\left.300 \mathrm{MHz}, \mathrm{CDCl}_{3}\right)$ : $7.76(\mathrm{~d}, J=2.26 \mathrm{~Hz}, 2 \mathrm{H}), 7.24(\mathrm{t}, J=2.26 \mathrm{~Hz}, 1 \mathrm{H}), 4.68$ (dd, $J=$ $3.04,12.23 \mathrm{~Hz}, 1 \mathrm{H}), 4.16(\mathrm{dd}, J=6.42,12.23 \mathrm{~Hz}, 1 \mathrm{H}), 3.35(\mathrm{~m}$, $1 \mathrm{H}), 2.91(\mathrm{t}, J=4.40 \mathrm{~Hz}, 1 \mathrm{H}), 2.72(\mathrm{dd}, J=2.67,4.92 \mathrm{~Hz}, 1 \mathrm{H})$, 2.07 (s, $12 \mathrm{H}) ;{ }^{13} \mathrm{C}-\mathrm{NMR}\left(\delta, \mathrm{ppm}, 75 \mathrm{MHz}, \mathrm{CDCl}_{3}\right): 169.81,164.51$, 151.25, 132.17, 120.57, 119.77, 66.46, 54.87, 49.42, 44.92, 30.69; ESI-MS $m / z=528.94[\mathrm{M}+\mathrm{Na}]^{+}$(calcd 528.96 for $\mathrm{C}_{18} \mathrm{H}_{20} \mathrm{Br}_{2} \mathrm{O}_{7^{-}}$ $\mathrm{Na}$ ); IR ( $\left.\mathrm{cm}^{-1}\right): 2961,1754,1724,1596,1465,1440,1389,1368$, 1346, 1298, 1258, 1220, 1137, 1096, 997, 927, 906, 865, 790, 767, $745,682,652$.

\section{Synthesis of $2 \mathrm{a}$}

To a stirring solution of $1 \mathrm{a}(2.0 \mathrm{~g}, 4.42 \mathrm{mmol})$, trimethylolpropane diallyl ether $(1.09 \mathrm{~g}, 5.08 \mathrm{mmol})$, and dimethylaminopyridine (DMAP) $(0.108 \mathrm{~g}, 0.884 \mathrm{mmol})$ in THF $(20 \mathrm{~mL})$ was added DCC $(1.09 \mathrm{~g}, 5.30 \mathrm{mmol})$ in several portions at $0{ }^{\circ} \mathrm{C}$. The resulting reaction mixture was then stirred at room temperature for 12 hours. After this time, the reaction mixture was cooled to $0{ }^{\circ} \mathrm{C}$. This resulted in the precipitation of dicyclohexylurea (DCU) that was removed through filtration. The filtrate was concentrated under reduced pressure and the crude thus obtained was purified by silica gel column chromatography using heptane : EtOAc solvent gradient (98:2 to $95: 5$ ) to afford $1.6 \mathrm{~g}$ of the product as a colourless viscous liquid (yield $=56 \%$ ). ${ }^{1} \mathrm{H}$ $\operatorname{NMR}\left(\delta, \mathrm{ppm}, 300 \mathrm{MHz}, \mathrm{CDCl}_{3}\right): 7.69(\mathrm{~d}, J=2.21 \mathrm{~Hz}, 2 \mathrm{H}), 7.21(\mathrm{t}$, $J=2.21 \mathrm{~Hz}, 1 \mathrm{H}), 5.86(\mathrm{~m}, 2 \mathrm{H}), 5.18(\mathrm{~m}, 4 \mathrm{H}), 4.32(\mathrm{~s}, 2 \mathrm{H}), 3.95(\mathrm{~d}$, $J=5.53 \mathrm{~Hz}, 4 \mathrm{H}), 3.40(\mathrm{~s}, 4 \mathrm{H}), 2.07(\mathrm{~s}, 12 \mathrm{H}), 1.53(\mathrm{q}, J=7.47 \mathrm{~Hz}$, $2 \mathrm{H}), 0.91(\mathrm{t}, J=7.47 \mathrm{~Hz}, 3 \mathrm{H}) ;{ }^{13} \mathrm{C}-\mathrm{NMR}\left(\delta, \mathrm{ppm}, 75 \mathrm{MHz}, \mathrm{CDCl}_{3}\right)$ : 169.81, 164.62, 151.21, 135.06, 133.15, 120.24, 119.34, 116.79, 72.48, 70.49, 66.56, 54.97, 42.77, 30.67, 23.33, 7.80; ESI-MS m/z $=647.08[\mathrm{M}+\mathrm{H}]^{+}$(calcd 647.08 for $\left.\mathrm{C}_{27} \mathrm{H}_{37} \mathrm{Br}_{2} \mathrm{O}_{8}\right)$; IR $\left(\mathrm{cm}^{-1}\right)$ : 2933, 1758, 1726, 1596, 1462, 1443, 1391, 1370, 1350, 1299, 1256, 1224, 1134, 1095, 990, 925, 764, 681, 654.

\section{Synthesis of 2}

To a stirring solution of $2 \mathbf{a}(1.6 \mathrm{~g}, 2.46 \mathrm{mmol})$ in $\mathrm{CHCl}_{3}(10 \mathrm{~mL})$, was added a solution of $70 \% m$-chloroperoxybenzoic acid $(3.4 \mathrm{~g}$, $19.74 \mathrm{mmol})$ in $\mathrm{CHCl}_{3}(25 \mathrm{~mL})$ at $0{ }^{\circ} \mathrm{C}$ in a drop wise fashion. The resulting reaction mixture was stirred at room temperature for 20 hours, and then washed with $0.3 \mathrm{M} \mathrm{NaOH}(2 \times 25 \mathrm{~mL})$ and water $(25 \mathrm{~mL})$, dried over $\mathrm{Na}_{2} \mathrm{SO}_{4}$, and concentrated under reduced pressure to give a colourless liquid. This crude product was purified by silica gel column chromatography using a DCM : EtOAc solvent gradient (99: 1 to $95: 5$ ) to afford $0.79 \mathrm{~g}$ of the product as a colourless viscous liquid. (Yield $=47 \%$ ). ${ }^{1} \mathrm{H}$ $\operatorname{NMR}\left(\delta, \mathrm{ppm}, 300 \mathrm{MHz}, \mathrm{CDCl}_{3}\right): 7.71(\mathrm{~d}, J=2.24 \mathrm{~Hz}, 2 \mathrm{H}), 7.21(\mathrm{t}$, $J=2.24 \mathrm{~Hz}, 1 \mathrm{H}), 4.31(\mathrm{~s}, 2 \mathrm{H}), 3.72(\mathrm{~m}, 2 \mathrm{H}), 3.48(\mathrm{~m}, 4 \mathrm{H}), 3.36(\mathrm{~m}$, $2 \mathrm{H}), 3.10(\mathrm{~m}, 2 \mathrm{H}), 2.75(\mathrm{t}, J=4.85 \mathrm{~Hz}, 2 \mathrm{H}), 2.56(\mathrm{dd}, J=2.79$, $4.97 \mathrm{~Hz}, 2 \mathrm{H}), 2.07(\mathrm{~s}, 12 \mathrm{H}), 1.54(\mathrm{q}, J=7.58 \mathrm{~Hz}, 2 \mathrm{H}), 0.91(\mathrm{t}, J=$ $7.58 \mathrm{~Hz}, 3 \mathrm{H}) ;{ }^{13} \mathrm{C}-\mathrm{NMR}\left(\delta\right.$, ppm, $\left.75 \mathrm{MHz}, \mathrm{CDCl}_{3}\right):$ 169.68, 164.49, 151.11, 132.89, 120.15, 119.25, 72.11, 72.09, 71.51, 66.17, 54.87, $50.89,44.02,42.82,30.52,23.07,7.62$; ESI-MS $m / z=696.10[\mathrm{M}+$ $\left.\mathrm{NH}_{4}\right]^{+}$(calcd 696.07 for $\mathrm{C}_{27} \mathrm{H}_{40} \mathrm{Br}_{2} \mathrm{NO}_{8}$ ); IR $\left(\mathrm{cm}^{-1}\right.$ ): 2924, 1756, 1722, 1595, 1461, 1442, 1388, 1371, 1300, 1258, 1225, 1133, 1097, 997, 902, 848, 764, 684, 654. 


\section{Epoxy functionalized polymer 3}

Atom transfer radical polymerization (ATRP) initiator 1 (0.03 g, $0.059 \mathrm{mmol})$, methyl methacrylate $(5.08 \mathrm{~g}, 50.77 \mathrm{mmol})$, pentamethyldiethylenetriamine (PMDETA) (0.032 g, $0.188 \mathrm{mmol})$, and anisole $(7.0 \mathrm{~mL})$ were taken in a Schlenk tube and degassed by two freeze-pump-thaw cycles. $\mathrm{Cu}(\mathrm{I}) \mathrm{Br}(0.013 \mathrm{~g}, 0.94 \mathrm{mmol})$ was added to the frozen solution and degassed again by one freeze-pump-thaw cycle. The reaction mixture was then stirred under nitrogen atmosphere in a pre-heated oil bath at $35^{\circ} \mathrm{C}$ for 90 minutes. After this time, the reaction vessel was opened to air, cooled to room temperature, and precipitated into $400 \mathrm{~mL}$ of methanol. The precipitated polymer was isolated by filtration and purified by passing through a small plug of silica gel using DCM $(150 \mathrm{~mL})$ as eluent. The collected fractions were concentrated and precipitated into $300 \mathrm{~mL}$ of methanol. The polymer precipitate was collected by filtration and dried to give $0.64 \mathrm{~g}$ of the product as a white powder (monomer conversion $13 \%$ ). ${ }^{1} \mathrm{H}$ NMR ( $\delta$, ppm, $300 \mathrm{MHz}, \mathrm{CDCl}_{3}$ ): 7.61 (br s, 2H), 7.08 (br s, 1H), 4.67 (d, $J=12.21 \mathrm{~Hz}, 1 \mathrm{H}), 4.16(\mathrm{~m}, 1 \mathrm{H}), 3.84-3.35$ (br s, backbone, $\left.-\mathrm{OCH}_{3}\right), 2.91(\mathrm{t}, J=4.53 \mathrm{~Hz}, 1 \mathrm{H}), 2.72(\mathrm{~m}, 1 \mathrm{H}), 2.13-0.63$ (br m, backbone); GPC: $M_{\mathrm{n}}=15000, M_{\mathrm{w}}=19500$, PDI $\left(M_{\mathrm{w}} / M_{\mathrm{n}}\right)$ $=1.3$; IR $\left(\mathrm{cm}^{-1}\right): 2955,1723,1481,1441,1387,1268,1240,1193$, 1145, 987, 965, 840, 750 .

\section{Epoxy functionalized polymer 4}

Atom transfer radical polymerization (ATRP) initiator $2(0.03 \mathrm{~g}$, $0.044 \mathrm{mmol})$, methyl methacrylate $(5.07 \mathrm{~g}, 50.70 \mathrm{mmol})$, PMDETA (0.032 g, $0.185 \mathrm{mmol})$, and anisole $(7.0 \mathrm{~mL})$ were taken in a Schlenk tube and degassed by two freeze-pump-thaw cycles. $\mathrm{Cu}(\mathrm{I}) \mathrm{Br}(0.013 \mathrm{~g}, 0.92 \mathrm{mmol})$ was added to the frozen solution and degassed again by one freeze-pump-thaw cycle. The reaction mixture was then stirred under nitrogen atmosphere in a pre-heated oil bath at $35{ }^{\circ} \mathrm{C}$ for 90 minutes. After this time, the reaction vessel was opened to air, cooled to room temperature, and precipitated into $400 \mathrm{~mL}$ of methanol. The precipitated polymer was isolated by filtration and purified by passing through a small plug of silica gel using DCM $(150 \mathrm{~mL})$ as eluent. The collected fractions were concentrated and precipitated into $300 \mathrm{~mL}$ of methanol. The polymer precipitate was collected by filtration and dried to give $0.77 \mathrm{~g}$ of the product as a white powder (monomer conversion 15\%). ${ }^{1} \mathrm{H}-\mathrm{NMR}$ ( $\delta$, ppm, $300 \mathrm{MHz}, \mathrm{CDCl}_{3}$ ): 7.57 (br s, 2H), 7.03 (br s, 1H), 4.29 (s, 2H), 3.84-3.35 (br s, backbone, $\left.-\mathrm{OCH}_{3}\right), 3.10(\mathrm{~s}, 2 \mathrm{H}), 2.76(\mathrm{t}, J$ $=4.83 \mathrm{~Hz}, 2 \mathrm{H}), 2.57$ (m, 2H), 2.07-0.63 (br m, backbone); GPC: $M_{\mathrm{n}}=26300, M_{\mathrm{w}}=33200, \operatorname{PDI}\left(M_{\mathrm{w}} / M_{\mathrm{n}}\right)=1.2 ; \operatorname{IR}\left(\mathrm{cm}^{-1}\right): 2961$, 1723, 1447, 1270, 1239, 1189, 1142, 993, 966, 839, 746.

\section{Thiol functionalized polymer 5 (using LiOH as a base)}

To a stirring solution of polymer $3(0.13 \mathrm{~g}, 0.0081 \mathrm{mmol})$ and 1thionaphthol $(0.019 \mathrm{~g}, 0.12 \mathrm{mmol})$ in THF $(1.5 \mathrm{~mL})$, was added LiOH $(0.204 \mathrm{mg}, 0.0048 \mathrm{mmol})$ in $0.040 \mathrm{~mL}$ of water (a stock solution was prepared before) at $0{ }^{\circ} \mathrm{C}$. The resulting reaction mixture was stirred for 18 hours at ambient temperature. THF was evaporated and the crude polymer was dissolved in DCM $(20 \mathrm{~mL})$ and washed with water $(10 \mathrm{~mL})$. The organic layer was dried, concentrated, and the polymer obtained was dissolved in a minimum quantity of DCM and precipitated into $\mathrm{MeOH}$ (50 $\mathrm{mL}$ ), then filtered and dried to give $0.12 \mathrm{~g}$ of the product (yield $=$ 91\%). ${ }^{1} \mathrm{H}$-NMR $\left(\delta\right.$, ppm, $\left.300 \mathrm{MHz}, \mathrm{CDCl}_{3}\right): 8.44(\mathrm{~d}, J=8.27 \mathrm{~Hz}$, $1 \mathrm{H}), 7.85(\mathrm{~d}, J=7.64 \mathrm{~Hz}, 1 \mathrm{H}), 7.77(\mathrm{~d}, J=8.01 \mathrm{~Hz}, 1 \mathrm{H}), 7.70(\mathrm{~d}, J$ $=7.27 \mathrm{~Hz}, 1 \mathrm{H}), 7.62-7.38(\mathrm{br} \mathrm{m}, 5 \mathrm{H}), 7.08$ (br s, 1H), $4.42(\mathrm{~m}$, $2 \mathrm{H}), 4.08$ (br s, $1 \mathrm{H}), 3.84-3.34$ (br s, backbone $-\mathrm{OCH}_{3}$ ), 3.20 (br s, $2 \mathrm{H}$ ), 2.07-0.63 (br m, backbone); GPC: $M_{\mathrm{n}}=15800, M_{\mathrm{w}}=$ 20400 , PDI $\left(M_{\mathrm{w}} / M_{\mathrm{n}}\right)=1.3$; IR $\left(\mathrm{cm}^{-1}\right): 2955,1723,1481,1441$, 1387, 1268, 1240, 1193, 1145, 987, 965, 840, 750.

\section{Thiol functionalized polymer 5 (using TEA as a base)}

To a stirring solution of polymer $3(0.030 \mathrm{~g}, 0.00187 \mathrm{mmol})$ and 1-thionaphthol $(0.014 \mathrm{~g}, 0.09 \mathrm{mmol})$ in THF $(0.3 \mathrm{~mL})$, was added TEA $(0.113 \mathrm{~g}, 0.112 \mathrm{mmol})$ at ambient temperature. The resulting reaction mixture was stirred for 16 hours. The solvent was reduced under low pressure and the crude polymer was dissolved in DCM (4 mL) and washed with water. The organic layer was dried, concentrated, and the polymer obtained was dissolved in a minimum quantity of DCM and precipitated into $\mathrm{MeOH}(30 \mathrm{~mL})$, then filtered and dried to give $0.025 \mathrm{~g}$ of the product in $82 \%$ yield.

\section{Thiol functionalized polymer 6 (using LiOH as a base)}

To a stirring solution of polymer $4(0.1 \mathrm{~g}, 0.005 \mathrm{mmol})$ and 1thionaphthol $(0.024 \mathrm{~g}, 0.15 \mathrm{mmol})$ in THF $(1.5 \mathrm{~mL})$, was added LiOH $(0.188 \mathrm{mg}, 0.0045 \mathrm{mmol}$ ) in $0.037 \mathrm{~mL}$ of water (a stock solution was prepared before) at $0{ }^{\circ} \mathrm{C}$. The resulting reaction mixture was stirred for 18 hours at ambient temperature. THF was evaporated and the crude polymer was dissolved in DCM $(20 \mathrm{~mL})$ and washed with water $(10 \mathrm{~mL})$. The organic layer was dried, concentrated, and the polymer obtained was dissolved in a minimum quantity of DCM and precipitated into $\mathrm{MeOH}$ (50 $\mathrm{mL}$ ), then filtered and dried to give $0.092 \mathrm{~g}$ of the product (yield $=91 \%) .{ }^{1} \mathrm{H}-\mathrm{NMR}\left(\delta, \mathrm{ppm}, 300 \mathrm{MHz}, \mathrm{CDCl}_{3}\right): 8.39(\mathrm{~d}, J=8.26 \mathrm{~Hz}$, $2 \mathrm{H}), 7.83(\mathrm{~d}, J=7.54 \mathrm{~Hz}, 2 \mathrm{H}), 7.73(\mathrm{~d}, J=7.71 \mathrm{~Hz}, 2 \mathrm{H}), 7.61(\mathrm{~d}, J$ $=7.20 \mathrm{~Hz}, 2 \mathrm{H}), 7.53(\mathrm{~m}, 6 \mathrm{H}), 7.38(\mathrm{t}, J=7.94 \mathrm{~Hz}, 2 \mathrm{H}), 7.03(\mathrm{br} \mathrm{s}$, $1 \mathrm{H}), 4.23(\mathrm{~s}, 2 \mathrm{H}), 3.84-3.35$ (br s, backbone $\left.-\mathrm{OCH}_{3}\right), 3.09(\mathrm{~m}$, $4 \mathrm{H}$ ), 2.07-0.63 (br m, backbone); GPC: $M_{\mathrm{n}}=25500, M_{\mathrm{w}}=$ 33700 , PDI $\left(M_{\mathrm{w}} / M_{\mathrm{n}}\right)=1.3$; IR $\left(\mathrm{cm}^{-1}\right): 2961,1723,1447,1270$, 1239, 1189, 1142, 993, 966, 839, 746.

\section{Thiol functionalized polymer 6 (using TEA as a base)}

To a stirring solution of polymer $4(0.020 \mathrm{~g}, 0.001 \mathrm{mmol})$ and 1thionaphthol $(0.020 \mathrm{~g}, 0.128 \mathrm{mmol})$ in THF $(0.4 \mathrm{~mL})$, was added TEA (0.0161 g, $0.16 \mathrm{mmol})$ at ambient temperature. The resulting reaction mixture was stirred for 16 hours. The solvent was removed and the crude polymer was dissolved in DCM (4 $\mathrm{mL}$ ) and washed with water. The organic layer was dried, concentrated, and the polymer obtained was dissolved in a minimum quantity of DCM and precipitated into $\mathrm{MeOH}(30$ $\mathrm{mL}$ ), then filtered and dried to give $0.016 \mathrm{~g}$ of the product in $78 \%$ yield. 


\section{Bifunctional polymer 7}

To a stirring solution of polymer $5(0.060 \mathrm{~g})$ in pyridine $(1 \mathrm{~mL})$, was added $p$-toluoyl chloride $(0.1 \mathrm{~mL})$ at $0{ }^{\circ} \mathrm{C}$. The reaction mixture was stirred at $0{ }^{\circ} \mathrm{C}$ for 1 hour and then at room temperature for 18 hours. Pyridine was removed under reduced pressure and the crude polymer thus obtained was dissolved in DCM $(10 \mathrm{~mL})$ and washed with water $(10 \mathrm{~mL})$, saturated aqueous solution of $\mathrm{NaHCO}_{3}(10 \mathrm{~mL})$, and $0.5 \mathrm{M} \mathrm{HCl}$ solution $(10 \mathrm{~mL})$. The organic layer was dried, concentrated, and the polymer thus obtained was dissolved in a minimum amount of DCM and precipitated into $\mathrm{MeOH}(40 \mathrm{~mL})$. The precipitate was collected by filtration, washed with $\mathrm{MeOH}$, and dried to give $0.05 \mathrm{~g}$ of the product (yield $=82 \%) .{ }^{1} \mathrm{H}-\mathrm{NMR}(\delta, \mathrm{ppm}, 300 \mathrm{MHz}$, $\left.\mathrm{CDCl}_{3}\right): 8.42(\mathrm{~d}, J=8.30 \mathrm{~Hz}, 1 \mathrm{H}), 7.77(\mathrm{~m}, 5 \mathrm{H}), 7.55-7.38(\mathrm{~m}$, $5 \mathrm{H}), 7.18$ (d, $J=8.03 \mathrm{~Hz}, 2 \mathrm{H}), 7.04$ (br s, 1H), 5.52 (m, 1H), 4.65 (m, 2H), 3.84-3.34 (br m, backbone - $\mathrm{OCH}_{3}$ ), 2.40 (s, 3H), 2.070.63 (br m, backbone); GPC: $M_{\mathrm{n}}=14900, M_{\mathrm{w}}=19500$, PDI $\left(M_{\mathrm{w}} / M_{\mathrm{n}}\right)=1.3$ IR $\left(\mathrm{cm}^{-1}\right): 2955,1723,1481,1441,1387,1268$, 1240, 1193, 1145, 987, 965, 840, 750 .

\section{Bifunctional polymer 8}

To a stirring solution of polymer $6(0.050 \mathrm{~g})$ in pyridine $(1 \mathrm{~mL})$, was added $p$-toluoyl chloride $(0.08 \mathrm{~mL})$ at $0{ }^{\circ} \mathrm{C}$. The reaction mixture was stirred at $0{ }^{\circ} \mathrm{C}$ for 1 hour and then at room temperature for 18 hours. Pyridine was removed under reduced pressure and the crude polymer thus obtained was dissolved in DCM $(10 \mathrm{~mL})$ and washed with water $(10 \mathrm{~mL})$, saturated solution of $\mathrm{NaHCO}_{3}(10 \mathrm{~mL})$, and $0.5 \mathrm{M} \mathrm{HCl}$ solution $(10 \mathrm{~mL})$. The organic layer was dried, concentrated, and the polymer thus obtained was dissolved in a minimum amount of DCM and precipitated into $\mathrm{MeOH}(40 \mathrm{~mL})$. The precipitate was collected by filtration, washed with $\mathrm{MeOH}$, and dried to give $0.042 \mathrm{~g}$ of the product (yield $=83 \%) .{ }^{1} \mathrm{H}-\mathrm{NMR}\left(\delta, \mathrm{ppm}, 300 \mathrm{MHz}, \mathrm{CDCl}_{3}\right): 8.36$ $(\mathrm{d}, J=8.14 \mathrm{~Hz}, 2 \mathrm{H}), 7.72(\mathrm{~m}, 10 \mathrm{H}), 7.50(\mathrm{~m}, 6 \mathrm{H}), 7.35(\mathrm{t}, J=$ $7.72 \mathrm{~Hz}, 2 \mathrm{H}), 7.12$ (d, $J=7.76 \mathrm{~Hz}, 4 \mathrm{H}), 7.02(\mathrm{br} \mathrm{s}, 1 \mathrm{H}), 5.28(\mathrm{~m}$, $2 \mathrm{H}$ ), 4.16 (s, 2H), 3.84-3.33 (br m, backbone $\left.-\mathrm{OCH}_{3}\right), 2.35$ (s, 6H), 2.07-0.64 (br m, backbone); GPC: $M_{\mathrm{n}}=27300, M_{\mathrm{w}}=$ 35 900, PDI $\left(M_{\mathrm{w}} / M_{\mathrm{n}}\right)=1.3$; IR $\left(\mathrm{cm}^{-1}\right): 2961,1723,1447,1270$, 1239, 1189, 1142, 993, 966, 839, 746.

\section{Hydrolysis of 3}

To a solution of polymer $3(50 \mathrm{mg}, 0.0031 \mathrm{mmol})$ in THF $(2 \mathrm{~mL})$ and $\mathrm{MeOH}(2 \mathrm{~mL}), \mathrm{NaOH}(51 \mathrm{mg}, 1.281 \mathrm{mmol})$ was added and the reaction mixture was refluxed at $65^{\circ} \mathrm{C}$ for $20 \mathrm{hr}$. The solvent was then removed under reduced pressure and the crude thus obtained was suspended in water and then filtered. The solid was then washed with $\mathrm{MeOH}$. Same procedure was employed for the hydrolysis of polymer 4 .

\section{Results and discussion}

To investigate the feasibility of the aforementioned concept, ATRP-based polymerization initiators carrying one (1) and two (2) epoxide groups along with two initiating sites were designed (Scheme 2). It was envisaged that polymerization from such dual initiating species would give rise to polymer chains having

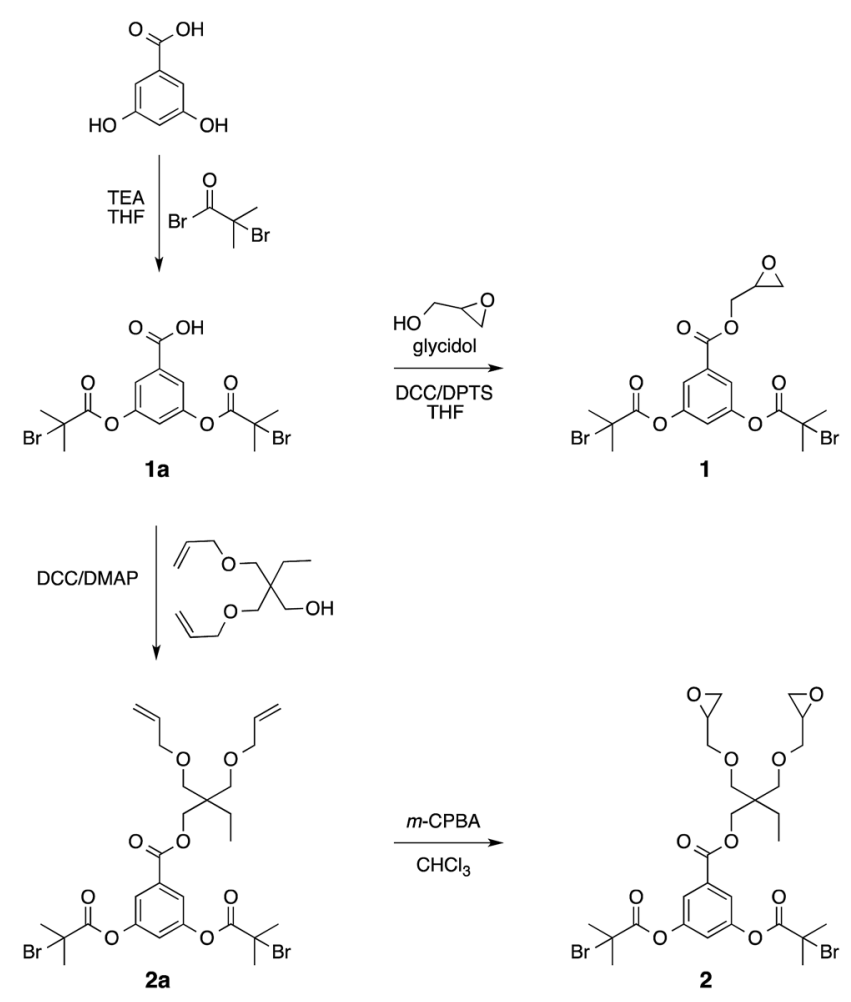

Scheme 2 Synthesis of polymerization initiators.

reactive epoxide unit(s) at the midpoint of a polymer chain. To achieve synthesis of these initiators, 3,5-dihydroxybenzoic acid was subjected to an esterification reaction with bromoisobutyryl bromide (Scheme 2). The resulting benzoic acid derivative 1a was further subjected to an esterification reaction with glycidol molecule to give initiator $\mathbf{1}$. To obtain initiator 2, 1a was converted into the olefin derivative 2a through an esterification reaction and then epoxidized using $m$-perchlorobenzoic acid in chloroform to furnish initiator $2 .{ }^{1} \mathrm{H}-\mathrm{NMR}$ spectroscopy confirmed the structure of these initiators as epoxy proton resonances could be observed in the range of 2.5-3.5 ppm and the aromatic proton resonances could be located in the range of 7-8 ppm (Fig. 1). This aromatic unit is referred to as the core unit in the forthcoming discussion. Initially, initiators $\mathbf{1}$ and 2 were subjected to a reaction with 1-naphthalenethiol using LiOH or triethylamine as a base. From this study, it became clear that thiol-halide reaction also occurred along with the thiol-epoxy reaction at the initiator level as two sets of aromatic resonances could be assigned to two different types of naphthalene substitutions (Fig. 2 and $\mathrm{S} 4 \dagger$ ).

Initiators $\mathbf{1}$ and $\mathbf{2}$ were then used for polymerization of methyl methacrylate monomer to give epoxide mid-functional poly(methyl methacrylate) (PMMA) polymers $3\left(M_{\mathrm{n}}=15 \mathrm{kDa}\right.$, $\left.M_{\mathrm{w}} / M_{\mathrm{n}}=1.3\right)$ and $4\left(M_{\mathrm{n}}=26 \mathrm{kDa}, M_{\mathrm{w}} / M_{\mathrm{n}}=1.2\right)$, respectively (Scheme 3). To confirm that the reactive centre was located at the centre of the polymer chain, the ester bonds that connect the polymer chain to the aromatic-core, in polymer 4, were hydrolysed under basic conditions (Scheme 4). This resulted in cleavage of the polymer chain into two fragments of nearly equal molecular weight $\left(M_{\mathrm{n}}=13 \mathrm{kDa}, M_{\mathrm{w}} / M_{\mathrm{n}}=1.2\right)$ (Fig. 3 and 


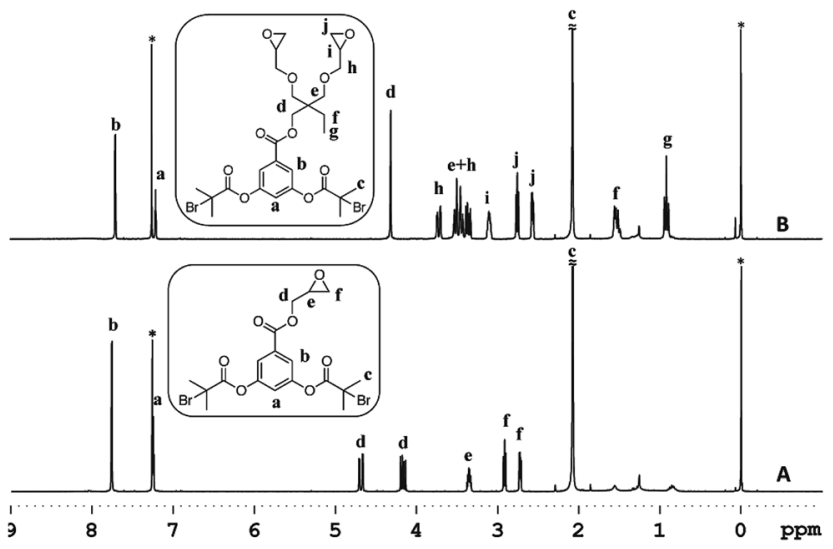

Fig. $1{ }^{1} \mathrm{H}-\mathrm{NMR}$ of the ATRP initiators $1(\mathrm{~A})$ and $2(\mathrm{~B})$ in $\mathrm{CDCl}_{3}$. Solvent signals are shown with an asterisk. Tetramethylsilane was used as an internal standard.

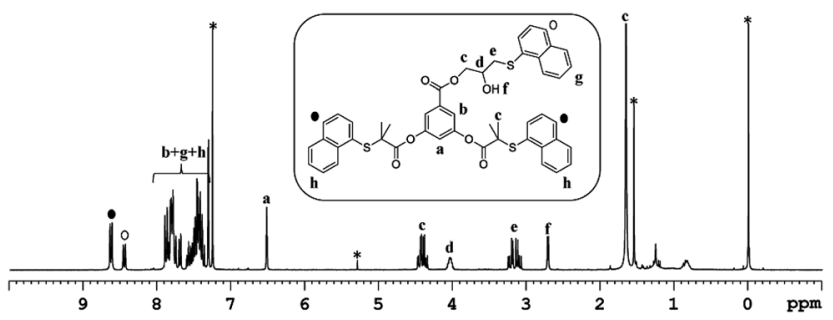

Fig. $2{ }^{1} \mathrm{H}-\mathrm{NMR}\left(\mathrm{CDCl}_{3}\right)$ of the product formed upon reaction of initiator 1 with 1-naphthalenethiol in the presence of $\mathrm{LiOH}$ as a base. Solvent signals are shown with an asterisk.

S5 $\dagger$ ). A similar result was obtained in the case of polymer 3. These experiments suggested that the reactive sites were located on the centre of the polymer chain.

To further investigate the cleavage chemistry, the polymer sample resulting from the hydrolysis reaction was purified and analysed by ${ }^{1} \mathrm{H}$-NMR spectroscopy (Fig. 4 and $\mathrm{S} 6 \dagger$ ). In this analysis, it became clear that the ester bonds that connect the polymer chains to the aromatic core were hydrolysed as the resonances from the aromatic core $(7-8 \mathrm{ppm})$ disappeared along with the methylene (4.2 ppm) and epoxide proton (2.5-3.5 ppm) signals in the ${ }^{1} \mathrm{H}$-NMR spectrum of the hydrolysed sample. The signals from the PMMA backbone (0.6-2.2 ppm), however, remained unchanged. More importantly, the integration of the methoxy-side chains of the polymer (3.3-3.9 ppm) matched with the integration of the polymer backbone suggesting that the side chain ester groups remained intact. This is in accordance with the previous polymer chain cleavage studies carried out under similar conditions on PMMA-based star polymers. $^{26}$

Having established the central location of the reactive site(s), the first modification of the epoxide unit(s) in polymers $\mathbf{3}$ and $\mathbf{4}$ was achieved using 1-naphthalenethiol (functionalization I in Scheme 3). This reaction was carried out in the presence of $\mathrm{LiOH}$ at room temperature. To ensure complete conversion of the sterically hindered epoxy units, an excess of the thiol reagent was utilized (epoxy : thiol/1:15). This resulted in the
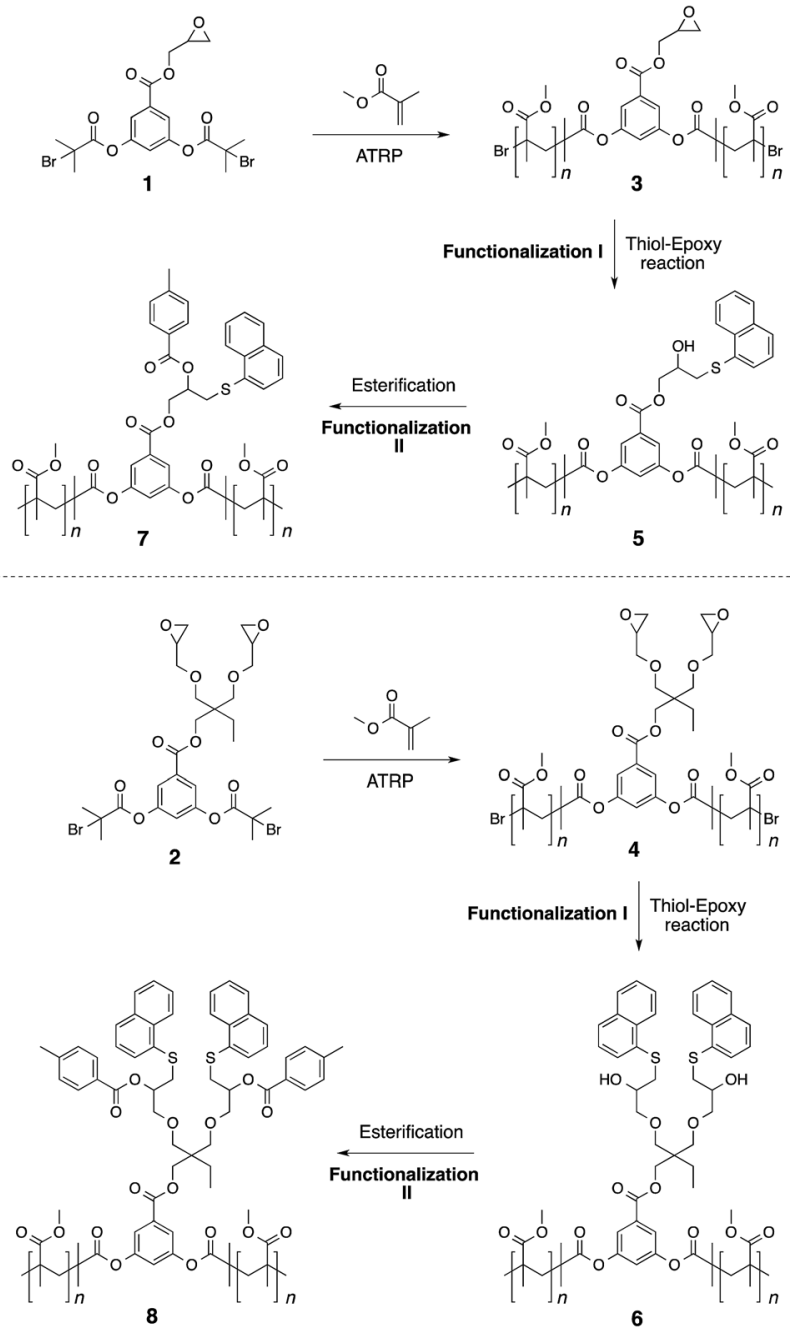

Scheme 3 Synthesis of polymers 7 and 8 .

formation of the thio-ether bond and generation of the hydroxyl unit. Use of triethylamine as a base (instead of LiOH) also produced the same results. However, in case of $\mathrm{LiOH}$, a catalytic amount was sufficient for thio-ether formation, whereas high excess of triethylamine is required for complete transformation of the epoxide group into the corresponding functionalized structure. Interestingly, only one set of aromatic proton resonances could be observed. Indicating that the halide-chain-end of the polymers did not participate in the substitution reaction as observed in the case of initiators. Modification of the

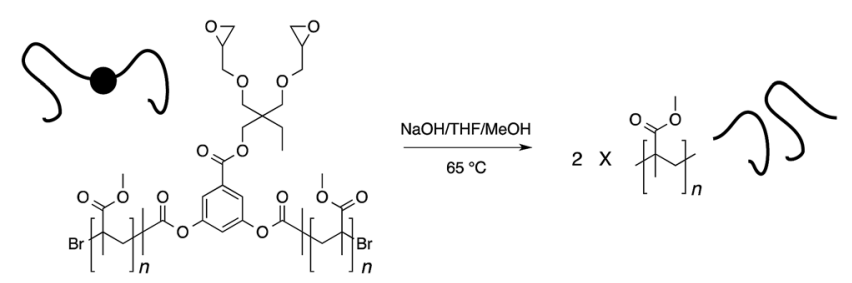

Scheme 4 Cleavage of the polymer chain to ascertain location of the reactive sites. 


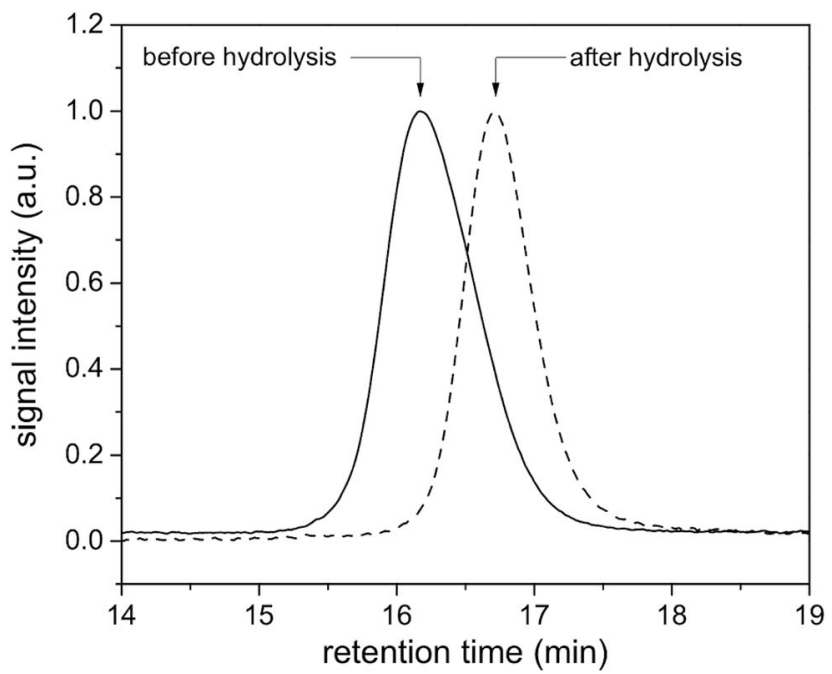

Fig. 3 GPC traces of the polymer 4 before (solid line) and after hydrolysis (dash line) in DMF.

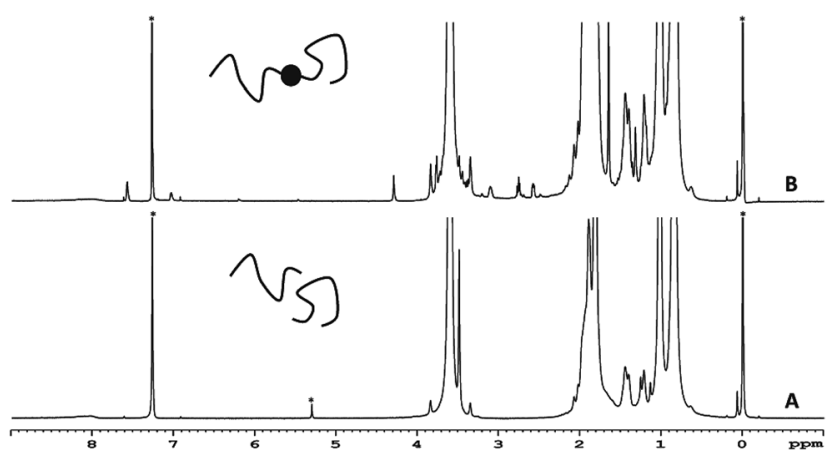

Fig. $4{ }^{1} \mathrm{H}$-NMR of the polymer 4 before $(B)$ and after hydrolysis (A) in $\mathrm{CDCl}_{3}$. Solvent signals are shown with an asterisk. Tetramethylsilane was used as an internal standard.

hydroxyl unit in polymers 5-6 with toluoyl chloride led to the formation of the targeted midpoint multifunctionalized structures 7 and 8 (functionalization II in Scheme 3). Once again, high excess of the acid chloride reagent was utilized due to the steric demand and relatively low reactivity of the secondary hydroxyl units (hydroxyl group : acid chloride/1 : 240).

The ${ }^{1} \mathrm{H}$-NMR spectrum of polymer $4(\mathrm{~A})$, and functionalized polymers 6 (B), and 8 (C) are shown in Fig. 5. Polymer 4 exhibited the characteristic proton resonances of the PMMA backbone in the range of $0.6-2.2$ and $3.3-3.9 \mathrm{ppm}$. The epoxy proton signals could be detected at $2.57,2.76$, and $3.1 \mathrm{ppm}$. The first functionalization resulted in the disappearance of the epoxy proton resonances and emergence of the aromatic proton signals from the naphthalene group (7.3-8.4 ppm). Based on the small molecule study, this set of aromatic proton resonances could be assigned to the thioether formed upon the thiol-epoxy reaction. Absence of the other set of the aromatic resonances suggested that the thiol-bromo reaction did not occur in the present set of materials. This may be due to the steric hindrance created by the methyl group of poly(methyl methacrylate). Besides absence of

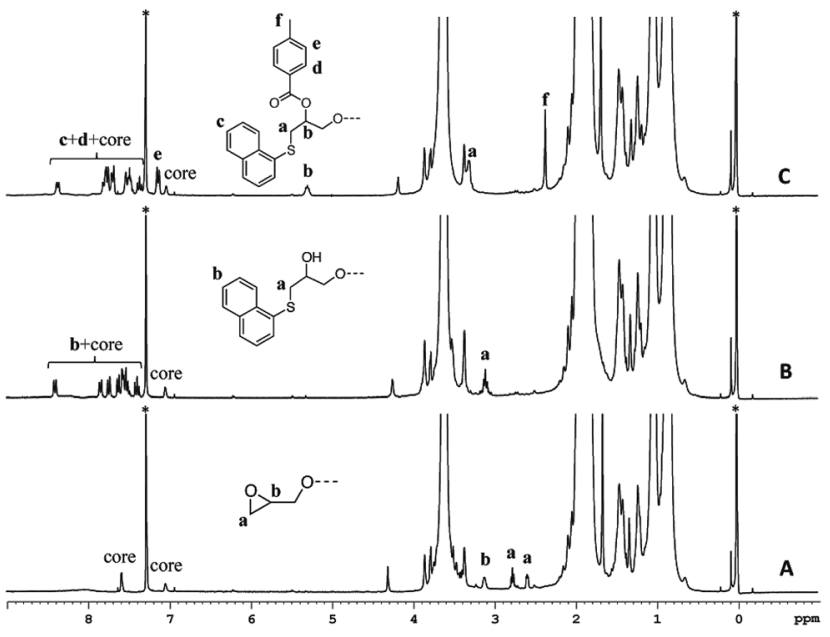

Fig. $5{ }^{1} \mathrm{H}-\mathrm{NMR}$ of polymer $4(\mathrm{~A})$, and end-functionalized polymers 6 (B) and 8 (C) in $\mathrm{CDCl}_{3}$. Solvent signals are shown with an asterisk. Tetramethylsilane was used as an internal standard.

a second set of aromatic signals, as seen at the initiator level, area integration analysis also suggested that the thiol-halide reaction did not occur (see Fig. S7† for area integration). UV-Vis spectroscopy also suggested a successful functionalization step as the absorption band centred on $300 \mathrm{~nm}$ could be assigned to the naphthalene chromophore (Fig. 6 and S8†). For the second functionalization, toluoyl chloride was chosen as a reactant. This choice was made because the signal from the methyl group of the toluoyl unit emerges in a region of the ${ }^{1} \mathrm{H}-\mathrm{NMR}$ spectrum that is free from proton resonance signals of the polymer backbone and mid-chain groups. Moreover, this signal is high in intensity and resolution when compared to the other signals. This allowed us to determine the extent of hydroxyl group conversion with the help of ${ }^{1} \mathrm{H}$-NMR spectroscopy. The esterification of polymer 6 gave rise to polymer $\mathbf{8}$ and area integration analysis between the proton resonances of the toluoyl unit (designated 'e' and ' $\mathrm{f}$ ' in

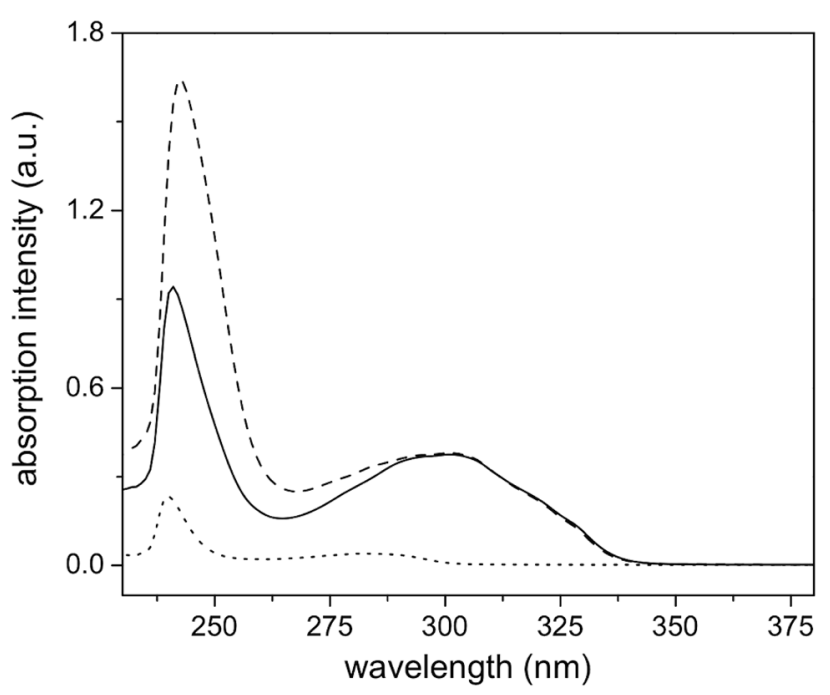

Fig. 6 UV-Vis absorption spectra of polymers 4 (dot line), 6 (solid line), and 8 (dash line) in chloroform. 
Fig. 5) and the naphthalene group suggested complete conversion of the hydroxyl units into the desired toluoyl esters (see Fig. $\mathrm{S} 9 \dagger$ for area integrations). The proton resonance signal at $5.28 \mathrm{ppm}$ could be ascribed to a proton located at the carbon adjacent to the newly formed ester group. In UV-Vis spectroscopy, the absorption band at $245 \mathrm{~nm}$ further increased in intensity after the esterification reaction (Fig. 6), most likely due to the incorporation of the toluoyl units in the molecular structure, once again suggesting successful functionalization of the polymer mid-chain through a sequential thiol-epoxy and esterification reaction.

To examine the effect of the functionalization reactions upon the hydrodynamic volume of the polymers, gel permeation chromatography (GPC) studies were undertaken. These studies established that the hydrodynamic volume of the precursor polymers and the functionalized structures remained the same as no changes in the retention time of the precursors and their functionalized analogues could be detected in the GPC chromatograms (Fig. S10 and S11†).

\section{Conclusions}

To summarize, a general synthetic strategy for midpoint multifunctionalization of a polymer chain is established. For this, ATRP polymerization initiators appended with one and two epoxide unit(s) along with two polymerization initiation sites were prepared. Polymerization of methyl methacrylate monomer by using these initiators gave access to polymers with epoxide unit(s) at the centre of the polymer chain. The hydrolysis study confirmed the midpoint location of the reactive site(s) on the polymer chain. The first mid-chain functionalization was achieved through the thiol-epoxy reaction that instated optically active naphthalene functionality and gave rise to a reactive hydroxyl group at the centre of the polymer chain. Further functionalization of the hydroxyl unit with toluoyl chloride then led to the formation of the targeted midpoint multifunctional materials. The number of the mid-chain functionalities could be adjusted by adjusting the number of epoxide unit(s) on the polymerization initiator. The functional group compatibility of the ATRP process and the cascade nature of the functionalization processes delivered the established strategy free from the protection/deprotection requirement of organic synthesis and allowed for facile preparation of complex yet well-defined multifunctional polymeric structures.

\section{Acknowledgements}

This work was by National Research Foundation of Korea grant funded by the Korea government (MSIP) (NRF2015R1D1A1A01057796 and 2015R1A2A2A01006008) and Global Frontier R\&D Program (No. 2013M3A6B1078869).

\section{Notes and references}

1 P. Theato and H.-A. Klok, Functional Polymers by PostPolymerization Modification, Wiley, Weinheim, Germany, 2013.
2 For excellent review articles, please see: $(a)$ C. J. Hawker and K. L. Wooley, Science, 2005, 309, 1200-1205; (b) J.-F. Lutz, Angew. Chem., Int. Ed., 2007, 46, 1018-1025; (c) R. K. Iha, K. L. Wooley, A. M. Nystrom, D. J. Burke, M. J. Kade and C. J. Hawker, Chem. Rev., 2009, 109, 5620-5686; (d) C. Barner-Kowollik and A. J. Inglis, Macromol. Chem. Phys., 2009, 210, 987-992; (e) A. Sanyal, Macromol. Chem. Phys., 2010, 211, 1417-1425; (f) U. Mansfeld, C. Pietsch, R. Hoogenboom, R. Becer and U. S. Schubert, Polym. Chem., 2010, 1, 1560-1598; (g) C. R. Becer, R. Hoogenboom and U. S. Schubert, Angew. Chem., Int. Ed., 2009, 48, 49004908; (h) B. S. Sumerlin and A. P. Vogt, Macromolecules, 2010, 43, 1-13; (i) H. Durmaz, A. Sanyal, G. Hizal and U. Tunca, Polym. Chem., 2012, 3, 825-835; (j) M. A. Harvison and A. B. Lowe, Macromol. Rapid Commun., 2011, 32, 779-800; (k) P. J. Roth, C. Boyer, A. B. Lowe and T. P. Davis, Macromol. Rapid Commun., 2011, 32, 11231143; (l) A. B. Lowe and M. A. Harvison, Aust. J. Chem., 2010, 63, 1251-1266; $(m)$ A. B. Lowe, C. E. Hoyle and C. N. Bowman, J. Mater. Chem., 2010, 20, 4745-4750; (n) W. H. Binder and R. Sachsenhofer, Macromol. Rapid Commun., 2007, 28, 15-54; (o) K. A. Gunay, P. Theato and H. A. Klok, J. Polym. Sci., Part A: Polym. Chem., 2012, 51, 1-28. 3 For selected examples, please see: (a) M. Malkoch, R. J. Thibault, E. Drockenmuller, M. Messerschmidt, B. Voit, T. P. Russell and C. J. Hawker, J. Am. Chem. Soc., 2005, 127, 14942-14949; (b) L. M. Campos, K. L. Killops, R. Sakai, J. M. J. Paulusse, D. Damiron, E. Drockenmuller, B. W. Messmore and C. J. Hawker, Macromolecules, 2008, 41, 7063-7070; (c) S. Ghosh, S. Basu and S. Thayumanavan, Macromolecules, 2006, 39, 5595-5597; (d) R. C. Li, J. Hwang and H. D. Maynard, Chem. Commun., 2007, 3631-3633; (e) S. K. Yang and M. Weck, Macromolecules, 2008, 41, 346351; $(f)$ A. V. Ambade, C. Burd, M. N. Higley, K. P. Nair and M. Weck, Chem.-Eur. J., 2009, 15, 11904-11911; $(g)$ N. T. Brummelhuis and M. Weck, ACS Macro Lett., 2012, 1, 1216-1218; (h) E. M. Kolonko, J. K. Pontrello, S. L. Mangold and L. L. Kiessling, J. Am. Chem. Soc., 2009, 131, 7327-7333; (i) N. Cengiz, H. Kabadayioglu and R. Sanyal, J. Polym. Sci., Part A: Polym. Chem., 2010, 48, 4737-4746; (j) J. B. Uprety, J. F. Reuther and B. M. Novak, Macromolecules, 2012, 45, 8155-8165; (k) K. A. McEwan, S. Slavin, E. Tunnah and D. M. Haddleton, Polym. Chem., 2013, 4, 2608-2614; (l) X. X. Deng, L. Li, Z. L. Li, A. Lv, F. S. Du and Z. C. Li, ACS Macro Lett., 2012, 1, 1300-1303; (m) A. Lv, X. X. Deng, L. Li, Z. L. Li, Y. Z. Wang, F. S. Du and Z. C. Li, Polym. Chem., 2013, 4, 3659; (n) R. Kakuchi and P. Theato, Polym. Chem., 2014, 5, 2320-2326; (o) R. Kakuchi and P. Theato, ACS Macro Lett., 2013, 2, 419-422. 4 For protective-group-free multifunctionalization of polymers, please see: A. Saha, S. De, M. C. Stuparu and A. Khan, J. Am. Chem. Soc., 2012, 134, 17291-17297.

5 (a) C. Ott, R. Hoogenbomm and U. S. Schubert, Chem. Commun., 2008, 3516-3518; (b) E. M. Kolonko and L. L. Kiessling, J. Am. Chem. Soc., 2008, 130, 5626-5627; (c) I. Kosif, E. J. Park, R. Sanyal and A. Sanyal, Macromolecules, 2010, 43, 4140-4148; (d) S. Onbulak, S. Tempelaar, 
R. J. Pounder, O. Gok, R. Sanyal, A. P. Dove and A. Sanyal, Macromolecules, 2012, 45, 1715-1722; (e) L. Billiet, D. Fournier and F. D. Prez, J. Polym. Sci., Part A: Polym. Chem., 2008, 46, 6552-6564; (f) D. Fournier and F. D. Prez, Macromolecules, 2008, 41, 4622-4630; $(g)$ L. Billiet, D. Fournier and F. D. Prez, Polymer, 2009, 50, 3877-3886; (h) P. Espeel, F. Goethals, F. Driessen, L.-T. T. Nguyen and F. D. Prez, Polym. Chem., 2013, 4, 2449-2456; (i) M. V. Walter, P. Lundberg, A. Hult and M. Malkoch, J. Polym. Sci., Part A: Polym. Chem., 2011, 49, 2990-2995; (j) Y. Y. Durmaz, M. Sangermano and Y. Yagci, J. Polym. Sci., Part A: Polym. Chem., 2010, 48, 2862-2868; (k) G. Yilmaz, H. Toiserkani, D. O. Demirkol, S. Sakarya, S. Timur, Y. Yagci and L. Torun, J. Polym. Sci., Part A: Polym. Chem., 2011, 49, 110-117; (l) M. Stemmelen, F. Pessel, V. Lapinte, S. Caillol, J.-P. Habas and J.-J. Robin, J. Polym. Sci., Part A: Polym. Chem., 2011, 49, 2434-2444; $(m)$ M. E. Buck and D. M. Lynn, Polym. Chem., 2012, 3, 66-80.

6 For excellent review articles, please see: $(a)$ R. P. Quirk and D. L. Pickel, Polym. Sci., 2012, 6, 351-412; (b) M. A. Tasdelen, M. U. Kahveci and Y. Yagci, Prog. Polym. Sci., 2005, 36, 455-567; (c) F. L. Verso and C. N. Likos, Polymer, 2008, 49, 1425-1434; (d) S. Hilf and A. F. M. Kilbinger, Nat. Chem., 2009, 1, 537-546; (e) M. A. Harvison, P. J. Roth, T. P. Davis and A. B. Lowe, Aust. J. Chem., 2011, 64, 992-1006.

7 For protective-group-free multifunctionalization of polymer chain-end, please see: (a) I. Gadwal and A. Khan, Polym. Chem., 2013, 4, 2440-2444; (b) Y. Kohsaka, K. Yamamoto and T. Kitayama, Polym. Chem., 2015, 6, 3601-3607.

8 For selected examples, please see: (a) M. P. Robin, M. W. Jones, D. M. Haddleton and R. K. O'Reilly, ACS Macro Lett., 2012, 1, 222-226; (b) S. Hilf, R. H. Grubbs and A. F. M. Kilbinger, J. Am. Chem. Soc., 2008, 130, 1104011048; (c) S. Hilf and A. F. M. Kilbinger, Macromolecules, 2009, 42, 4127-4133; (d) S. Hilf and A. F. M. Kilbinger, Macromolecules, 2010, 43, 208-212; (e) A. A. Nagarkar, A. Crochet, K. M. Fromm and A. F. M. Kilbinger, Macromolecules, 2012, 45, 4447-4453; (f) G. N. Grover, S. N. S. Alconcel, N. M. Matsumoto and H. D. Maynard, Macromolecules, 2009, 42, 7657-7663; $(g)$ L. Tao, C. S. Kaddis, R. R. Ogorzalek Loo, G. N. Grover, J. A. Loo and H. D. Maynard, Macromolecules, 2009, 42, 8028-8033; (h) K. L. Heredia, Z. P. Tolstyka and H. D. Maynard, Macromolecules, 2007, 40, 4772-4779; (i) A. P. Narrainen, L. R. Hutchings, I. Ansari, R. L. Thompson and N. Clarke, Macromolecules, 2007, 40, 1969-1980; (j) I. A. Ansari, N. Clarke, L. R. Hutchings, A. P. Narrainen, A. E. Terry, R. L. Thompson and J. R. P. Webster, Langmuir, 2007, 23, 4405-4413; $(k)$ L. R. Hutchings, A. P. Narrianen, R. L. Thompson, N. Clarke and I. Ansari, Polym. Int., 2008, 57, 163-170.

9 (a) D. Colak, I. Cianga, A. E. Muftuoglu and Y. Yagci, J. Polym. Sci., Part A: Polym. Chem., 2006, 44, 727-743; (b) B. Iskin, G. Yilmaz and Y. Yagci, Polym. Chem., 2011, 2, 2865-2871.

10 (a) E. Gungor, G. Cote, T. Erdogan, H. Durmaz, A. L. Demirel, G. Hizal and U. Tunca, J. Polym. Sci., Part A: Polym. Chem.,
2007, 45, 1055-1065; (b) O. Altintas, G. Hizal and U. Tunca, J. Polym. Sci., Part A: Polym. Chem., 2008, 46, 1218-1228; (c) O. Altintas, A. L. Demirel, G. Hizal and U. Tunca, J. Polym. Sci., Part A: Polym. Chem., 2008, 46, 5916-5928; (d) A. Gozgen, A. Dag, H. Durmaz, O. Sirkecioglu, G. Hizal and U. Tunca, J. Polym. Sci., Part A: Polym. Chem., 2009, 47, 497-504.

11 (a) L. Tao, J. Xu, D. Gell and T. P. Davis, Macromolecules, 2010, 43, 3721-3727; (b) L. Tao, J. Liu and T. P. Davis, Biomacromolecules, 2009, 10, 2847-2851; (c) A. Debuigne, M. Hurtgen, C. Jérôme and C. Detrembleur, ACS Symp. Ser., 2012, 217-230; (d) M. Degirmenci, A. Acikses and N. Genli, J. Appl. Polym. Sci., 2012, 123, 2567-2573; (e) C. Li, J. Hu, J. Yin and S. Liu, Macromolecules, 2009, 42, 5007-5016; (f) A. Hanisch, H. Schmalz and A. H. E. Müller, Macromolecules, 2012, 45, 8300-8309; $(g)$ K. Yue, J. He, C. Liu, M. Huang, X.-H. Dong, K. Guo, P. Ni, C. Wesdemiotis, R. P. Quirk, S. Z. D. Cheng and W.-B. Zhang, Chin. J. Polym. Sci., 2013, 31, 71-82.

12 M. Beija, M.-T. Charreyre and J. M. G. Martinho, Prog. Polym. Sci., 2011, 36, 568-602.

13 Multi-Component and Sequential Reactions in Polymer Synthesis, ed. P. Theato, Springer International Publishing, Heidelberg, 2015, vol. 269.

14 M. C. Stuparu and A. Khan, J. Polym. Sci., Part A: Polym. Chem., 2016, 54, 3057-3070.

15 (a) T. E. Patten, J. Xia, T. Abernathy and K. Matyjaszewski, Science, 1996, 272, 866-868; (b) J.-S. Wang and K. Matyjaszewski, J. Am. Chem. Soc., 1995, 117, 5614-5615; (c) K. Matyjaszewski, T. E. Patten and J. Xia, J. Am. Chem. Soc., 1997, 119, 674-680.

16 (a) K. Matyjaszewski and J. Xia, Chem. Rev., 2001, 101, 29212990; (b) N. V. Tsarevsky and K. Matyjaszewski, Chem. Rev., 2007, 107, 2270-2299.

17 P. L. Golas and K. Matyjaszewski, Chem. Soc. Rev., 2010, 39, 1338-1354.

18 For synthesis of polymers with reactive chain-ends via ATRP, please see: (a) K. Matyjaszewski, Y. Nakagawa and S. G. Gaynor, Macromol. Rapid Commun., 1997, 18, 10571066; (b) Y. Nakagawa and K. Matyjaszewski, Polym. J., 1998, 30, 138-141.

19 For synthesis of polymers with an epoxy chain-end via ATRP, please see: (a) N. V. Tsarevsky, S. A. Bencherif and K. Matyjaszewski, Macromolecules, 2007, 40, 4439-4445; (b) X. Zhang, J. Xia and K. Matyjaszewski, Macromolecules, 2000, 33, 2340-2345; (c) M. Degirmenci, O. Izgin, A. Acikses and N. Genli, React. Funct. Polym., 2010, 70, 28-34. 20 For synthesis of random copolymers and block copolymers carrying epoxide units via ATRP, please see: S. De, C. Stelzer and A. Khan, Polym. Chem., 2012, 3, 2342-2345.

21 For synthesis of well-defined polyglycidyl methacrylates, please see: (a) M. Rodlert, E. Harth, I. Rees and C. J. Hawker, J. Polym. Sci., Part A: Polym. Chem., 2000, 38, 4749-4763; (b) D. Damiron, J. Mazzolini, F. Cousin, C. Boisson, F. D'Agosto and E. Drockenmuller, Polym. Chem., 2012, 3, 1838-1845; (c) A. Moayeri, B. Lessard and M. Maric, Polym. Chem., 2011, 2, 2084-2092; (d) 
P. F. Caňamero, J. L. de la Fuente, E. L. Madruga and M. Ferngauenter. Pa, Macromol. Chem. Phys., 2004, 205, 2221-2228; (e) C. S. Gudipati, M. B. H. Tan, H. Hussain, Y. Liu, C. He and T. P. Davis, Macromol. Rapid Commun., 2008, 29, 1902-1907; (f) H. Gao, M. Elsabahy, E. V. Giger, D. Li, R. E. Prud'homme and J.-C. Leroux, Biomacromolecules, 2010, 11, 889-895; $(g)$ Q. Zhang, S. Slavin, M. W. Jones, A. J. Haddleton and D. M. Haddleton, Polym. Chem., 2012, 3, 1016-1023; $(h)$ A. Hayek, Y. Xu, T. Okada, S. Barlow, X. Zhu, J. H. Moon, S. R. Marder and S. Yang, J. Mater. Chem., 2008, 18, 33163318; (i) H. Zhu, Q. Liu and Y. Chen, Langmuir, 2007, 23, 790-794; (j) M. Ma, F. Li, F.-J. Chen, S.-X. Cheng and R.-X. Zhuo, Macromol. Biosci., 2010, 10, 183-191; (k) R. París, M. Liras and I. Quijada-Garrido, Macromol. Chem. Phys., 2011, 212, 1859-1868.

22 S. De and A. Khan, Chem. Commun., 2012, 48, 3130-3132. 23 (a) A. Brändle and A. Khan, Polym. Chem., 2012, 3, 32243227; (b) I. Gadwal, J. Rao, J. Baettig and A. Khan, Macromolecules, 2014, 47, 35-40; (c) I. Gadwal,
M. C. Stuparu and A. Khan, Polym. Chem., 2015, 6, 13931404; (d) S. Binder, I. Gadwal, A. Bielmann and A. Khan, J. Polym. Sci., Part A: Polym. Chem., 2014, 52, 2040-2046; (e) I. Gadwal and A. Khan, RSC Adv., 2015, 5, 43961-43964; (f) C. Buerkli, S. H. Lee, E. Moroz, M. C. Stuparu, J. C. Leroux and A. Khan, Biomacromolecules, 2014, 15, 1707-1715; $(g)$ D. Zhang, C. Liu, S. Chen, J. Zhang, J. Cheng and M. Miao, Prog. Org. Coat., 2016, 101, 178-185.

24 (a) S. Li, J. Han and C. Gao, Polym. Chem., 2013, 4, 17741787; (b) J. S. Basuki, L. Esser, H. T. T. Duong, Q. Zhang, P. Wilson, M. R. Whittaker, D. M. Haddleton, C. Boyer and T. P. Davis, Chem. Sci., 2014, 5, 715-726.

25 (a) F. S. Gungor and B. Kiskan, React. Funct. Polym., 2014, 75, 51-55; (b) B. Hanbeyoglu, B. Kiskan and Y. Yagci, Macromolecules, 2013, 46, 8434-8440; (c) A. Musa, B. Kiskan and Y. Yagci, Polymer, 2014, 55, 5550-5556.

26 L. Xue, U. S. Agarwal, M. Zhang, B. B. P. Staal, A. H. E. Müller, C. M. E. Bailly and P. J. Lemstra, Macromolecules, 2005, 38, 2093-2100. 